\title{
ASURANSI KESEHATAN BERDASARKAN UNDANG-UNDANG NOMOR 3 TAHUN 1992
}

\author{
Oleh: \\ Arief Suryono \\ Fakultas Hukum Universitas Jenderal Soedirman Purwokerto
}

\begin{abstract}
Health insurance according to the Law No. 3/1992 obout the social employment guarantee which consist of responsiver and the addressee and health service provider is the health social insurance which is aimed to give the health care guarantee toward the addressee that is enterprenaur and worker. The law relationship which is consisted between: Responssiver-Addressee is the insurance relationship; Responssiver-Health services provider is the user of health service belong to the health service provider toward to the addressee; Health services provider-Addressee is gives the health service to the addresse is patient. The responsibility of the responssiver toward the addressee is to give the health care insurance to the addressee gives the health service provider for the importance of the addressee.
\end{abstract}

Kata Kunci: Asuransi Kesehatan

\section{A. Pendahuluan}

Pada dasarnya setiap manusia dalam kehidupannya akan menghadapi risiko. Risiko yang dihadapi bagi setiap manusia tidak sama, namun pada dasarnya risiko tersebut dapat mengancam jiwa atau harta benda. Salah satu risiko jiwa yang dihadapi setiap manusia adalah adanya kemungkinan sakit. Dimana risiko adalah ketidakpastian yang dapat menimbulkan keuntungan atau kerugian. Dalam hubungannya dengan asuransi, yang dimaksud risiko adalah risiko yang dapat menimbulkan kerugian.

Manusia yang diberi akal pikiran diharapkan dapat mampu mengelola risiko sakit sehingga apabila risiko tersebut benar-benar terjadi tidak akan mengalami kerugian yang sangat besar. Salah satu cara untuk mengatasi risiko sakit adalah dengan asuransi kesehatan, karena tujuan asuransi kesehatan adalah untuk memperalihkan risiko sakit dari tertanggung kepada penanggung. Dimana tertanggung adalah pihak yang memperalihkan risiko, sedangkan penanggung adalah pihak yang menerima peralihan risiko yaitu Perusahaan Asuransi. Risiko sakit yang diperalihkan dengan cara asuransi kesehatan maksudnya adalah apabila tertanggung suatu saat mengalami sakit, maka penanggung akan memberikan pelayanan (biaya) perawatan kesehatan dalam upaya menyembuhkan sakitnya tertanggung.

Asuransi kesehatan merupakan bagian dari asuransi jiwa yang obyeknya jiwa. Tujuan asuransi kesehatan adalah memperalihkan risiko sakit dari tertanggung kepada penanggung. Sehingga kewajiban penanggung adalah memberikan pelayanan (biaya) perawatan kesehatan kepada tertanggung apabila sakit. Di mana sistem asuransi kesehatan bertujuan untuk melindungi masyarakat dari kesulitan (ekonomi) dalam pembiayaan pelayanan kesehatan ${ }^{1}$.

Secara umum asuransi diatur dalam Kitab Undang-undang Hukum Dagang (KUHD) dan Undang-Undang Nomor 2 Tahun 1992 tentang Usaha Perasuransian (UU No. 2/1992). Menurut Pasal 246 KUHD: Asuransi atau Pertanggungan adalah suatu perjanjian, di mana penanggung dengan menikmati suatu premi mengikat dirinya terhadap tertanggung untuk membebaskannya dari kerugian karena kehilangan, kerugian, atau ketiadaan keuntungan yang diharapkan, yang akan dapat diderita olehnya karena suatu kejadian yang tidak pasti. Sedangkan menurut Pasal 1 (1) UU No. 2/1992:

Sulastomo, 2000, Manajemen Kesehatan, Jakarta: PT Gramedia Pustaka Utama, hlm. 35 
214 Jurnal Dinamika Hukum

Vol. 9 No. 3 September 2009

Asuransi atau Pertanggungan adalah perjanjian antara dua pihak atau lebih, dengan mana pihak penanggung mengikatkan diri kepada tertanggung, dengan menerima premi asuransi, untuk memberikan penggantian kepada tertanggung karena kerugian, kerusakan atau kehilangan keuntungan yang diharapkan, atau tanggung jawab hukum kepada pihak ketiga yang mungkin akan diderita tertanggung yang timbul dari suatu peristiwa yang tidak pasti atau untuk memberikan pembayaran yang didasarkan atas meninggal atau hidupnya. Pengertian asuransi tersebut di atas disebut asuransi sukarela. Selain asuransi sukarela juga dikenal asuransi wajib atau sosial, dimana keberadaannya bersifat wajib berdasarkan peraturan perundang-undangan

Pengertian asuransi menurut Pasal 246 KUHD dan Pasal 1 (1) UU No. 2/1992 merupakan perjanjian antara tertanggung dengan penanggung, sehingga berlaku syarat-syarat syahnya perjanjian dan asas-asas hukum perjanjian yang melahirkan asuransi sukarela. Namun selain asuransi berdasarkan perjanjian juga dikenal adanya asuransi berdasarkan peraturan perundang-undangan yaitu asuransi sosial/wajib.

Lain halnya tentang jaminan pemeliharaan asuransi kesehatan yang diatur menurut Undang-Undang Nomor 3 Tahun 1992 tentang Jaminan Sosial Tenaga Kerja (UU No. 3/1992). Adapun yang dimaksud tenaga kerja adalah setiap orang yang mampu melakukan pekerjaan baik di dalam maupun di luar hubungan kerja, guna menghasilkan jasa atau barang untuk memenuhi kebutuhan masyarakat (Pasal 1 (2) UU No. 3/1992). UU No. 3/1992 selain memberikan jaminan pemeliharaan asuransi kesehatan, juga memberikan: Jaminan Kecelakaan Kerja; Jaminan Kematian; dan Jaminan Hari Tua (Pasal 6 (1) UU No. 3/1992)

Secara garis besar sistem pembiayaan kesehatan dapat dibedakan menjadi 4 kelompok, yaitu: Pertama, berupa sistem pelayanan kesehatan nasional. Kedua, sistem pembiayaan kesehatan yang diserahkan pada mekanisme pasar dengan dengan asuransi kesehatan profitkomersial sebagai pilar utamanya. Ketiga, sis- tem asuransi kesehatan sosial. Keempat, sistem pembiayaan kesehatan sosialis ${ }^{2}$

Berdasarkan hat tersebut di atas, penulis tertarik untuk membahas mengenai Bagaimanakah konstruksi hubungan hukum asuransi kesehatan menurut UU No. 3/1992 ?dan Bagaimanakah tanggung jawab penanggung menurut UU No. 3/1992? Dalam tulisan ini, penulis akan membahas tentang asuransi kesehatan, oleh karena itu, tulisan hanya akan membahas mengenai masalah jaminan pemeliharaan kesehatan dalam hal ini adalah asuransi kesehatan berdasarkan UU No. 3/1992.

\section{B. PEMBAHASAN}

\section{Penggolongan Asuransi}

\section{a. Asuransi Kerugian dan Asuransi Jiwa}

Menurut Pasal 246 yuncto Pasal 247 KUHD dikenal adanya asuransi kerugian dan asuransi jiwa dan menurut ketentuan Pasal 3 (a) dan Pasal 4 UU No. 2/1992, mengenal adanya asuransi kerugian dan asuransi jiwa. Adapun perbedaan asuransi kerugian dengan asuransi jiwa adalah:

1) Mengenai Para Pihak

Pertanggungan kerugian hanya dua pihak, yaitu pihak penanggung dan tertanggung, sedangkan dalam pertanggungan jumlah (jiwa), selain pihak penanggung, pihak tertanggung dapat memecah diri menjadi 3, yaitu:

a) Penutup (pengambil) asuransi, yakni orang yang menutup (mengambil asuransi), berkewajiban membayar premi dan berhak menerima polis.

b) Penikmat, yaitu orang yang ditunjuk oleh penutup asuransi untuk menerima prestasi dari penanggung.

c) Badan tertanggung yaitu orang yang jiwanya dipertanggungkan (pen.)

2) Mengenai Yang Dipertanggungkan

Ali Ghufron Mukti dan Moertjahjo, 2007, SISTEM JAMINAN KESEHATAN: Konsep Desentralisasi Terintegrasi, Yogyakarta: Magister Kebijakan Pembiayaan dan Manajemen Asuransi/Jaminan Kesehatan Fakultas Kedokteran Universitas Gadjah Mada dan Asosiasi Jaminan Sosial Daerah, hlm. 9 
Pertanggungan kerugian yang dipertanggungkan adalah barang. Sedangkan dalam pertanggungan jiwa (jumlah) yang dipertanggungkan adalah jiwa.

3) Mengenai Prestasi Penanggung

Pertanggungan kerugian, prestasi penang-gung adalah mengganti kerugian yang benar-benar diderita oleh tertanggung. Sedangkan dalam pertanggungan jiwa, prestasi penanggung adalah membayar sejumlah uang tertentu yang telah ditetapkan pada saat penutupan pertang-gungan.

4) Mengenai Kepentingan

Kepentingan pada pertanggungan kerugian adalah hak subyektif atau kewajiban yang bernilai uang, dapat diancam bahaya dan tidak dilarang oleh undang-undang (Pasal 268 KUHD). Sedangkan kepentingan pada pertanggungan jiwa bersifat immaterial.

5) Mengenai Evenemen

Evenemen pada pertanggungan kerugian berupa terjadinya peristiwa tak tentu yang menimbulkan kerugian pada tertanggung. Sedangkan yang dimaksud evenemen pada pertanggungan jiwa ialah meninggalnya jiwa seseorang atau lampaunya tenggang waktu pertanggungan tanpa meninggal.

6) Mengenai Asas Indemnitas

Asas indemnitas artinya asas ganti kerugian, yakni hanya kerugian yang benar-benar diderita oleh tertanggung yang diganti. Asas indemnitas berlaku bagi pertanggungan kerugian, namun tidak berlaku bagi pertanggungan jiwa ${ }^{3}$.

Untuk memahami asuransi kerugian dan asuransi jiwa, menurut penulis seharusnya perbedaan antara asuransi kerugian dengan asuransi jiwa adalah berdasarkan obyek asuransi. Kalau obyek

HMN Purwosutjipto, Pengertian Pokok Hukum Dagang Indonesia, Hukum Pertanggungan, Cet. Keempat, Jakarta: Djambatan, hlm. 17-18. asuransi berupa ben-da/barang, termasuk asuransi kerugian; namun apabila obyek asuransi berupa jiwa/manusia, termasuk asuransi jiwa.

b. Asuransi Sukarela dan Asuransi Wajib

Berdasarkan prosesnya asuransi, dikenal adanya asuransi sukarela dan asuransi wajib. Asuransi sukarela terjadi apabila dikehendaki para pihak antara tertanggung dan penanggung. Asuransi sukarela lahir berdasarkan perjanjian yang dibuat antara tertanggung dengan penanggung, sehingga berlaku syaratsyarat dan asas-asas hukum perjanjian.

Asuransi wajib terjadi karena berdasarkan peraturan perundang-undangan. Sehingga tidak ada kebebasan antara tertanggung dan penanggung dalam menentukan pilihannya sesuai yang dikehendaki. Semua hak dan kewajiban sudah ditentukan berdasarkan peraturan perundang-undangan.

c. Asuransi Komersial dan Asuransi Sosial

Asuransi komersial/sukarela yaitu perjanjian asuransi yang bersifat sukarela diselenggarakan atas kehendak pribadi dengan maksud untuk melindungi dirinya dari kemungkinan terjadi kerugian karena suatu peristiwa yang tidak tertentu ${ }^{4}$. Asuransi komersial lebih ditujukan untuk kepentingan risiko pribadi tertanggung terhadap risiko kerugian yang dihadapi. Hal ini diharapkan agar apabila terjadi kerugian tertanggung secara ekonomis akan memperoleh ganti rugi dari penanggung. Jadi lebih tertuju kepada kepentingan ekonomi ${ }^{5}$.

Asuransi sosial pada dasarnya memberikan perlindungan kepada masyarakat luas, terhadap semua kemungkinan kerugian yang diderita di luar kemampuan

Man Suparman Sastrawidjaja dan Endang, 1993, Kedudukan Hukum Asuransi Sosial Dalam Pengaturan Undang-Undang Hukum Asuransi Nasional Serta Kemungkinan Pengembangan Ruang Lingkupnya, Yogyakarta: Universitas Gadjah Mada, hlm. 124

5 Arief Suryono, 2003, op.cit. hlm. 86 
216 Jurnal Dinamika Hukum

Vol. 9 No. 3 September 2009

orang-orang pribadi. ${ }^{6}$ Social insurance is any government insurance intended to protect people in low income groups again economic and industrial hazard: in includes accident insurance, unemployment insurance, health insurance, old age pensions, and maternity insurance. ${ }^{7}$ Asuransi sosial berdasarkan peraturan perundang-undangan, bukan berdasarkan perjanjian antara tertanggung dengan penanggung.

Adapun unsur-unsur asuransi sosial adalah:

1) Diselenggarakan karena ditetapkan oleh peraturan perundang-undangan;

2) Perikatan yang terjadi antara para pihak lahir karena undang-undang mengharuskan;

3) Mempunyai sifat wajib bagi mereka yang memenuhi persyaratan perundang-undangan yang bersangkutan;

4) Pada umumnya yang bertindak sebagai penyeleggara atau penanggung adalah pemerintah;

5) Lebih diutamakan perlindungan kepada hal-hal yang berhubungan dengan risiko sosial dari pada risiko individual;

6) Ditujukan untuk memberikan suatu jaminan sosial kepada masyarakat atau kelompok masyarakat, dan bukan dimaksudkan untuk mencari keuntungan;

7) Perbandingan antara premi dan santunan (benefit) diatur secara progresif;

8) Besarnya premi ditetapkan oleh pemerintah dengan peraturan perundang-undangan, dan lebih ditetapkan kepada kepantasan masyarakat (social adequacy) dari pada keadilan pribadi (private equaty); dan

Sri Redjeki Hartono, 1985, Hukum Dagang, AsuransiDan Hukum Auransi Di Indonesia, Cet. Pertama, Semarang: IKIP Semarang Press, hlm. 185

Hasbullah Thabrani, Asuransi Kesehatan, Pilihan Kebijakan Nasional, Jakarta: Fakultas Kesehatan Masyarakat Univrsitas Indonesia, hlm. 11
9) Tidak ada pilihan mengenai masalah kepentingan dan peristiwa (evenement) ${ }^{8}$.

Berdasarkan unsur-unsur asuransi sosial seperti tersebut di atas, maka dengan menggunakan teori contrario, berarti unsur-unsur asuransi komersial adalah:

1) Diselenggarakan bukan karena ditetapkan oleh peraturan perundang-undangan;

2) Perikatan yang terjadi antara tertanggung dengan penanggung berdasarkan perjanjian;

3) Bersifat sukarela bagi mereka yang bersangkutan;

4) Penanggung bias swasta atau pemerintah;

5) Diutamakan untuk perlindungan terhadap risiko individual;

6) Ditujukan untuk kepentingan individual (pada umumnya) dan dimaksudkan untuk mencari keuntungan;

7) Perbandingan antara premi dan santunan proporsional;

8) Besarnya premi ditetapkan berdasarkan perjanjian;

9) Besarnya santunan ditetapkan berdasarkan perjanjian; dan

10) Adanya pilihan bagi tertanggung mengenai kepentingan dan peristiwa (evenement) yang akan diasuransikan? Berdasarkan uraian tersebut di atas, penggolongan asuransi komersial dan asuransi sosial lebih mengarah kepada tujuannya. Asuransi komersial diadakan oleh penanggung sebagai bisnis dengan tujuan utamanya mencari untung. Asuransi komersial juga dikenal sebagai asuransi sukarela, karena lahirnya asuransi komersial berdasarkan perjanjian antara tertanggung dengan penanggung, sehingga berlaku syarat-syarat dan asas-asas hukum perjanjian. Sedangkan asuransi sosial bersifat wajib, diselenggarakan oleh Pemerintah berdasarkan per-

Man Suparman Sastrawidjaja dan Endang, op.cit, $\mathrm{hlm} .130-131$

9 Arief Suryono, 2003, op.cit, hlm. 89-90 
aturan perundang-undangan dengan tujuan memberikan jaminan sosial untuk memenuhi kebutuhan hidup pokok masyarakat atau sebagian anggota masyarakat tertentu dan tidak mencari keuntungan dalam upaya meningkatkan kesejahteraan masyarakat ${ }^{10}$.

Berdasarkan uraian tersebut di atas, maka asuransi kesehatan Jaminan Sosial Tenaga Kerja termasuk asuransi sosial (wajib).

\section{Risiko Kesehatan}

Kesehatan merupakan hak asasi manusia. Setiap orang berhak atas taraf hidup yang memadai untuk kesehatan dan kesejahteraan diri dan keluarganya sebagaimana Pasal 25 Deklarasi Umum Hak Asasi Manusia Perserikatan Bangsa-Bangsa. ${ }^{11}$

Upaya peningkatan kualitas hidup manusia di bidang kesehatan, merupakan suatu usaha yang sangat luas dan menyeluruh, usaha tersebut meliputi peningkatan kesehatan masyarakat baik fisik maupun non fisik. $^{12}$

Risiko dalam asuransi merupakan ketidakpastian mengenai kerugian. Sehingga risiko dalam asuransi mengandung dua konsep, yaitu ketidakpastian dan kerugian. Titik berat pengertian risiko pada asuransi ialah pada ketidakpastian dan bukan pada kerugian. ${ }^{13}$ Lebih lanjut dikatakan bahwa Ketidakpastian di sini yang dimaksudkan adalah ketidakpastian akan terjadi atau tidak terjadinya suatu peristiwa yang menciptakan kerugian. Hal ini adalah sesuai dengan fungsi dasar asuransi.

10 Arief Suryono, 2008, Asuransi Kesehatan Sosial: Sebagai Upaya Negara Dalam Mewujudkan Masyarakat Sejahtera, YUSTISIA, Jurnal Hukum, Terakreditasi, Edisi 74, Mei-Agustus 2008, Tahun XVIII, Surakarta: Fakultas Hukum Universitas Sebelas Maret, hlm. 107

11 Muhammad Mulyadi Ali dkk, Editor, 2007, Kemitraan Dalam Hubungan Dokter-Pasien, Jakarta: Konsil Kedokteran Indonesia, hlm. 6

12 Bahder Johan Nasution, 2005, Hukum Kesehatan, Pertanggungjawaban Dokter, Jakarta: PT Rineka Cipta, hlm. 1

13 Sri Redjeki Hartono, 1990, Reasuransi, Kebutuhan Yang Tidak Dapat Dikesampingkan Oleh Penanggung Guna Memenuhi Kewajiban Terhadap Tertanggung, Tinjauan Yuridis, Semarang: Universitas Diponegoro, hlm. 7
Fungsi dasar asuransi ialah merupakan suatu upaya untuk menanggulangi ketidakpastian terhadap kerugian khusus untuk kerugian-kerugian murni dan bukan kerugian yang bersifat spekulatif. ${ }^{14}$

Adapun unsur-unsur risiko adalah:

a. Ketidakpastian antara harapan dan kenyataan;

b. Identik (pada umumnya) dengan kerugian; dimana kerugian ini kemungkinan dapat terjadi pada masa yang akan datang, dan kerugian ini terjadinya tidak bisa dipastikan sebelumnya;

c. Erat hubungannya dengan asuransi (risiko merupakan bagian pokok dalam asuransi). ${ }^{15}$

Risiko sakit pada dasarnya akan selalu dihadapi oleh setiap manusia, hanya saat kapan risiko tersebut akan terjadi yang tidak bisa dipastikan. Apabila risiko sakit benarbenar terjadi maka diperlukan usaha bagaimana untuk mengatasi risiko dengan upaya menyembuhkan sakitnya agar tidak berkelanjutan dan tidak mengganggu aktivitas yang dapat menimbulkan kerugian. Kesehatan merupakan dambaan setiap manusia, oleh sebab itu hanya dengan sehatlah aktivitas dapat dilaksanakan secara maksimal.

Adapun risiko kesehatan terhadap setiap orang pada dasarnya dapat dipengaruhi oleh beberapa faktor, yaitu:

a. Faktor Usia

Faktopr usia berpengaruh terhadap risiko kesehatan. Semakin bertambahnya usia seseorang akan semakin mudah terserang penyakit tertentu.

b. Faktor Pekerjaan

Jenis pekerjaan yang dilakukan seseorang akan dapat berpengaruh terhadap tingkat risiko tertentu yang dapat menyebabkan seseorang mengalami gangguan kesehatannya. ${ }^{16}$

Sri Redjeki Hartono, Ibid, hlm. 7

Arief Suryono, 2003, Op.cit, hlm. 39

16 Ascobat Gani dan Yaslis Ilyas, 2000, Dasar-Dasar Asuransi Kesehatan, Bagian A, Jakarta: Pusat Kajian Ekonomi Kesehatan KM UI dan PT (Persero) Asuransi Kesehatan Indonesia, hlm. 119-121 
218 Jurnal Dinamika Hukum

Vol. 9 No. 3 September 2009

\section{c. Faktor Manusia}

Faktor manusia dapat terjadi karena kesalahan, ketidaktauhan atau kekurang hati-hatian sendiri atau kesalahan orang lain; dan

d. Faktor Alam

Dapat mempengaruhi terjadinya gangguan kesehatan. ${ }^{17}$

\section{Asuransi Kesehatan Menurut UU No.} 3/1992

Asuransi kesehatan (askes) merupakan asuransi yang obyeknya jiwa. Tujuan asuransi kesehatan adalah memperalihkan risiko biaya sakit dari tertanggung kepada penanggung. Sehingga kewajiban penanggung adalah memberikan biaya atau pelayanan perawatan kesehatan kepada tertanggung apabila sakit. ${ }^{18}$ Menurut Sulastomo, Sistem asuransi kesehatan bertujuan untuk melindungi masyarakat dari kesulitan (ekonomi) dalam pembiayaan pelayanan kesehatan. ${ }^{19}$ Ini yang dimaksud asuransi kesehatan sosial.

PT (Persero) Jaminan Sosial Tenaga Keja memberikan jaminan sosial bagi tenaga kerja. Menurut Pasal 1 (1) UU No. 3/1992: Jaminan sosial tenaga kerja adalah suatu perlindungan bagi tenaga kerja dalam bentuk santunan berupa uang sebagai pengganti sebagian dari penghasilan yang hilang atau berkurang dan pelayanan sebagai akibat peristiwa atau keadaan yang dialami oleh tenaga kerja berupa kecelakaan kerja, sakit, hamil, bersalin, hari tua, dan meninggal dunia.

Jaminan sosial tenaga kerja bersifat wajib ditujukan kepada: Pengusaha dan tenaga kerja (Pasal 17 UU No. 3/1992). Yang dimaksud pengusaha menurut Pasal 1 (3) UU No. 3/1992 adalah:

a. Orang, persekutuan atau badan hukum yang menjalankan suatu perusahaan milik sendiri;

17 Arief Suryono, 2003, op.cit, hlm. 68-69

18 Arief Suryono, 2008, "Asuransi Kesehatan Menurut Peraturan Pemerintah Nomor 69 Tahun 1991", HUMANIS, Jurnal Sosial Ekonomi Humaniora, Volume 2 Nomor 2, Nopember 2008, Purwokerto: Lembaga Penelitian Universitas Jenderal Soedirman, hlm. 102

19 Sulastomo, op.cit. hlm. 35 b. Orang, perskutuan atau badan hukum yang secara berdiri sendiri menjalankan perusahaan bukan miliknya; dan

c. Orang, persekutuan atau badan hokum yang berada di Indonesia, mewakili perusahaan sebagaiman dimaksud dalam huruf $a$ dan huruf $b$ yang berkedudukan di luar wilayah Indonesia.

Tenaga kerja adalah setiap orang yang mampu melakukabn pekerjaan baik di dalam maupun di luar hubungan kerja, guna menghasilkan jasa atau barang untuk memenuhi kebutuhan masyarakat [Pasal 1 (2) UU No. 3/1992].

Program jaminan sosial tenaga kerja bersifat wajib bagi: Pengusaha yang mempekerjakan tenaga kerja sebanyak 10 (sepuluh) orang atau lebih, atau membayar upah paling sedikit Rp. 1.000.000 (satu juta rupiah) sebulan, wajib mengikut sertakan tenaga kerjanya dalam program jaminan sosial tenaga kerja sebagaimana dimaksud dalam ayat (1) [Pasal 2 (3)] Peraturan Pemerintah Nomor 14 Tahun 1993 tentang "Penyelenggaraan Program Jaminan Sosial Tenaga Kerja" (PP No. 14/1993).

Unsur-unsur asuransi kesehatan adalah:

a. Penanggung

Berdasarkan Peraturan Pemerintah Nomor 36 Tahun 1995 tentang "Penetapan Badan Penyelenggara Program Jamsostek”, bahwa Perusahaan Perseroan (Persero) PT Astek yang didirikan berdasarkan Peraturan Pemerintah Nomor 19 Tahun 1990 ditetapkan sebagai badan penyelenggara program Jamsostek sebagaimana dimaksud UU No. 3/1992 dan merubah nama perusahaan perseroan (Persero) PT Astek menjadi perusahaan perseroan (Persero) PT Jaminan Sosial Tenaga Kerja (Jamsostek).

b. Tertanggung

Berdasarkan Pasal 17 UU No. 3/1992: Tertanggung adalah pengusaha dan tenaga kerja. Pengusaha yang mempekerjakan tenaga kerja sebanyak 10 (sepuluh) orang atau lebih, atau membayar upah paling sedikit Rp. 1.000.000 (satu juta 
rupiah) sebulan, wajib mengikut sertakan tenaga kerjanya dalam program jaminan sosial tenaga kerja sebagaimana dimaksud dalam ayat (1) [Pasal 2 (3)] PP No. 14/1993.

c. Pemberi Pelayanan Kesehatan (PPK). PPK PT (Persero) Jamsostek disebut Pelaksana Pelayanan Kesehatan (PPK). PPK adalah fasilitas (sarana) pelayanan kesehatan yang ditunjuk oleh PT (Persero) Jamsostek untuk melaksanakan pemeliharaan kesehatan bagi peserta, yang terdiri dari PPK Tk. I (Puskesmas, Balai Pengobatan, Klinik 24 Jam), PPK Tk. II (Rumah Sakit Pemerintah Umum atau Daerah/ Swasta/BUMN), Apotek BUMN/Swasta, Optikal BUMN/ Swasta, Laboratorium Swasta dan Koordinator PPK.

\section{Hubungan Hukum Asuransi Kesehatan} Menurut UU No. 3/1992

a. Hubungan Penanggung Dengan Tertanggung

Hubungan hukum antara penanggung dengan tertanggung adalah berdasarkan konsep asuransi. Dimana penanggung adalah PT (Persero) Jamsostek, sedangkan tertanggung adalah pengusaha dan tenaga kerja (Pasal 17 UU No. 3/1992). Hubungan hukum terjadi sejak pendaftaran dan pembayaran iuran (premi= penulis) pertama dilakukan oleh pengusaha (Pasal 7 PP No. 14/1993).

Hak penanggung adalah menerima pembayaran iuran, sedangkan kewajibannya adalah memberikan pemeliharaan kesehatan kepada tertanggung. Pemeliharaan kesehatan adalah upaya penanggulangan dan pencegahan gangguan kesehatan yang memerlukan pemeriksaan, pengobatan, dan/atau perawatan termasuk kehamilan dan persalinan [Pasal 1 (9) UU No. 3/1992]. Hak tertanggung adalah mendapatkan pemeliharaan kesehatan, sedangkan kewajiban tertanggung adalah membayar iuran jaminan pemeliharaan kesehatan sebesar $6 \%$ dari upah sebulan bagi tenaga kerja yang sudah berkeluarga, dan $3 \%$ dari upah sebulan bagi tenaga kerja yang belum berkeluarga [Pasal 9 (1d) PP No. 14/1993] yang ditanggung sepenuhnya oleh pengusaha [Pasal 9 (2) PP No. 14/1993].

b. Hubungan Penanggung Dengan PPK

1) Perjanjian Kerjasama Antara PT (Persero) Jamsostek Dengan Rumah Sakit (RS) tentang "Pemberian Pelayanan Kesehatan Bagi Peserta Program Jaminan Pemeliharaan Kesehatan (JPK)" (Perjanjian antara PT (Persero) Jamsostek dengan RS). Hubungan antara PT (Persero) Jamsostek dengan RS sebagai PPK adalah berupa hubungan pemberian pekerjaan antara Penanggung dengan PPK untuk memberikan pelayanan kesehatan kepada tertanggung [Pasal 2 (1) Perjanjian antara PT (Persero) Jamsostek dengan RS). Kewajiban penanggung kepada tertanggung adalah memberikan ganti rugi biaya yang sudah dilakukan RS kepada tertanggung berdasarkan rincian tariff yang sudah disetujui [Pasal 6 (1) Perjanjian antara PT (Persero) Jamsostek dengan RS]

2) Perjanjian Kerjasama Antara PT (Persero) Jamsostek Dengan Koordinator PPK tentang "Pelaksanaan Pelayanan Kesehatan Mlalui Koordinator PPK Bagi Peserta Program Jaminan Pemeliharaan Kesehatan" (Perjanjian antara PT (Persero) Jamsostek dengan Koordinator PPK). Hubungan antara PT (Persero) Jamsostek dengan Koordinator PPK adalah hubungan pekerjaan berupa menyerahkan seluruh pelayanan kesehatan, pengendalian biaya pelayanan kesehatan dan administrasi pelayanan kesehatan [Pasal 2 (1) Perjanjian antara PT (Persero) Jamsostek dengan Koordinator PPK], berdasarkan sistem kapitasi [Pasal 4 (2g) Perjanjian antara PT (Persero) Jamsostek dengan Koordinator PPK].

3) Perjanjian Kerjasama Antara PT (Persero) Jamsostek Dengan Dokter Umum 
Tentang "Pemberian Pelayanan Kesehatan Melalui Dokter Umum/Keluarga Bagi Peserta Program Jaminan Pemeliharaan Kesehatan (JPK)" (Perjanjian antara PT (Persero) Jamsostek dengan Dokter). Hubungan antara PT (Persero) Jamsostek dengan Dokter sebagai PPK adalah hubungan pekerjaan sebagai Pelaksana Pelayanan Kesehatan dengan tertanggung [Pasal 2 (1) Perjanjian antara PT (Persero) Jamsostek dengan Dokter], atas tanggung jawab biaya dari penanggung.

4) Perjanjian Kerjasama Antara PT (Persero) Jamsostek Dengan Apotek Tentang "Pemberian Pelayanan Obatobatan Melalui Apotek Bagi Peserta Program Jaminan Pemeliharaan Kesehatan (JPK)" (Perjanjian antara PT (Persero) Jamsostek dengan Apotek). Hubungan antara PT (Persero) Jamsostek dengan Apotek adalah hubungan pemberian pekerjaan berupa pelayanan dalam pemberian obatobatan [Pasal 2 (1) Perjanjian antara PT (Persero) Jamsostek dengan Apotek], atas tanggung jawab biaya dari penanggung.

c. Hubungan PPK Dengan Tertanggung

1) Hubungan Antara RS Dengan Tertanggung

RS yang dimaksud adalah RS yang telah ditunjuk PT (Persero) Jamsostek berdasarkan perjanjian antara PT (Persero) Jamsostek dengan RS, berupa pemberian pelayanan kesehatan [Pasal 2 (1) Perjanjian PT (Persero) Jamsostk Dengan RS] dari RS kepada tertanggung.

2) Hubungan Koordinator PPK Dengan Tertanggung

Koordinator PPK yang dimaksud adalah Koordinator PPK yang telah ditunjuk PT (Persero) Jamsostek berdasarkan perjanjian PT (Persero) Jamsostek dengan Koordinator PPK, berupa penyerahan seluruh pelayanan kesehatan, pengendalian biaya pelayanan ke- sehatan, administrasi pelayanan sesuai prosedur dan Juklak Pelayanan Kesehatan bagi tertanggung [Pasal 2 (1) Perjanjian PT (Persero) Jamsostek Dengan Koordinator PPK]. Kewajiban Koordinator PPK memberikan pelayanan kesehatan kepada tertanggung.

3) Hubungan Dokter Umum Dengan Tertanggung

Dokter Umum yang dimaksud adalah dokter umum yang telah ditunjuk PT (Persero) Jamsostek berdasarkan perjanjian PT (Persero) Jamsostek Dengan Dokter Umum, berupa penunjukan dari PT (Persero) Jamsostek kepada Dokter sebagai PPK bagi tertanggung [Pasal 2 (1) Perjanjian PT (Persero) Jamsostek Dengan Dokter Umum]. Kewajiban Dokter adalah memberikan pelayanan kesehatan kepada tertanggung.

4) Hubungan Apotek dengan Tertanggung Apotek yang dimaksud adalah apotek yang telah ditunjuk PT (Persero) Jamsostek berdasarkan perjanjian PT (Persero) Jamsostek Dengan Apotek, berupa penunjukan PT (Persero) Jamsostek kepada Apotek dalam pemberian obat-obatan atas pengajuan resep-resep obat yang dikeluarkan oleh Dokter yang ditunjuk PT (Persero) Jamsostek [Pasal 2 (1) Perjanjian PT (Persero) Jamsostek Dengan Apotek]. Kewajiban Apotek adalah memberikan pelayanan obat-obatan untuk kepentingan tertanggung.

\section{Penutup}

Berdasarkan uraian tersebut di atas dapat disimpulkan sebagai berikut:

1. Konstruksi hubungan hukum asuransi kesehatan menurut UU No. 3/1992, adalah:

a. Penanggung Dengan Tertanggung Hubungan hukum antara penanggung dengan tertanggung adalah berdasarkan konsep asuransi, dimana penanggung adalah PT (Persero) Jamsostek, sedangkan tertanggung adalah pengusaha dan tenaga kerja. 
b. Hubungan Penanggung Dengan PPK Hubungan hukum antara penanggung dengan PPK adalah merupakan hubungan hukum berupa penggunaan jasa pelayanan kesehatan milik PPK untuk kepentingan tertanggung.

c. PPK Dengan Tertanggung Hubungan hukum antara PPK dengan tertanggung adalah memberikan pelayanan kesehatan kepada tertanggung sebagai pasien.

2. Tanggung jawab penanggung kepada tertanggung menurut UU No. 3/1992, adalah:

a. Memberikan jaminan pelayanan pemeliharaan kesehatan kepada tertanggung.

b. Menyediakan PPK untuk kepentingan tertanggung.

\section{Daftar Pustaka}

Ali, Muhammad Mulyadi dkk (Ed). 2007. Kemitraan Dalam Hubungan Dokter-Pasien. Jakarta: Konsil Kedokteran Indonesia;

Gani, Ascobat dan Yaslis Ilyas. 2000. DasarDasar Asuransi Kesehatan, Bagian A. Jakarta: Pusat Kajian Ekonomi Kesehatan KM UI dan PT (Persero) Asuransi Kesehatan Indonesia;

Guwandi, J. 2007. Hukum Medik (Medical Law). Cet. Ke-3, Jakarta: Fakultas Kdokteran Universitas Indonesia;

Hartono, Siti Soemarti. 1983. K.U.H.D. (Kitab Undang-Undang Hukum Dagang) \& P.K. (Peraturan Kepailitan). Cetakan Ke Enam, Yogyakarta: Seksi Hukum Dagang Fakultas Hukum Universitas Gadjah Mada;

Hartono, Sri Redjeki. 1985. Hukum Dagang, AsuransiDan Hukum Auransi Di Indonesia. Cet. Pertama, Semarang: IKIP Semarang Press;

-. 1990. Reasuransi, Kebutuhan Yang Tidak Dapat Dikesampingkan Oleh Penanggung Guna Memenuhi Kewajiban Terhadap Tertanggung, Tinjauan Yuridis. Semarang: Universitas Diponegoro;

Mukti, Ali Ghufron dan Moertjahjo. 2007. SISTEM JAMINAN KESEHATAN: Konsep Desentralisasi Terintegrasi, Yogyakarta: Magister Kebijakan Pembiayaan dan Manajemen Asuransi/Jaminan Kesehatan
Fakultas Kedokteran Universitas Gadjah Mada dan Asosiasi Jaminan Sosial Daerah;

Nasution, Bahder Johan. 2005. Hukum Kesehatan, Pertanggungjawaban Dokter. Jakarta: PT Rineka Cipta;

Purwosutjipto, HMN. Pengertian Pokok Hukum Dagang Indonesia, Hukum Pertanggungan. Cet. Keempat, Jakarta: Djambatan;

Sastrawidjaja, Man Suparman dan Endang. 1993. Kedudukan Hukum Asuransi Sosial Dalam Pengaturan Undang-Undang $\mathrm{Hu}$ kum Asuransi Nasional Serta Kemungkinan Pengembangan Ruang Lingkupnya. Yogyakarta: Universitas Gadjah Mada;

Sulastomo. 2000. Manajemen Kesehatan, Jakarta: PT Gramedia Pustaka Utama;

Suryono, Arief. 2003. Tanggung Jawab Penanggung Dalam Asuransi Kesehatan Di Indonesia. Surabaya: Universitas Airlangga;

. 2008. Asuransi Kesehatan Menurut Peraturan Pemerintah Nomor 69 Tahun 1991. HUMANIS, Jurnal Sosial Ekonomi Humaniora, Volume 2 Nomor 2, Nopember 2008. Purwokerto: Lembaga Penelitian Universitas Jenderal Soedirman;

-. 2008. Asuransi Kesehatan Sosial: Sebagai Upaya Negara Dalam Mewujudkan Masyarakat Sejahtera. YUSTISIA, Jurnal Hukum, Terakreditasi, Edisi 74, MeiAgustus 2008, Tahun XVIII, Surakarta: FH Universitas Sebelas Maret;

Thabrani, Hasbullah. 1998. Asuransi Kesehatan, Pilihan Kebijakan Nasional. Jakarta: Fakultas Kesehatan Masyarakat Univrsitas Indonesia;

\section{Peraturan Perundang-undangan}

Undang-Undang Nomor 2 Tahun 1992 tentang Usaha Perasuransian

Undang-Undang Nomor 3 Tahun 1992 tentang Jaminan Sosial Tenaga Kerja

Peraturan Pemerintah Nomor 14 Tahun 1993 tentang Penyelenggaraan Program Jaminan Sosial Tenaga Kerja

Peraturan Pemerintah Nomor 36 Tahun 1995 tentang Penetapan Badan Penyelenggara Program Jamsostek 